\title{
Microfossil Correlation of California Lower Tertiary Sections: A Comparison
}

GEOLOGICAL SURVEY PROFESIONAL PAPER 743-F

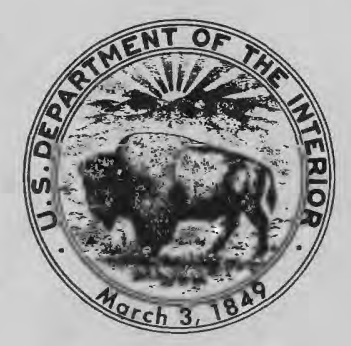




\section{Microfossil Correlation of California Lower Tertiary Sections: A Comparison}

By Richard Z. PoORe

SHORTER CONTRIBUTIONS TO GENERAL GEOLOGY

GEOLOGICA L S URVEY PROFESSIONAL PA PER $743-$ F

Synthesis of data on calcareous planktonic microfossils from lower Tertiary sections in

California: implications for correlations and

age assignments based on benthic foraminifers

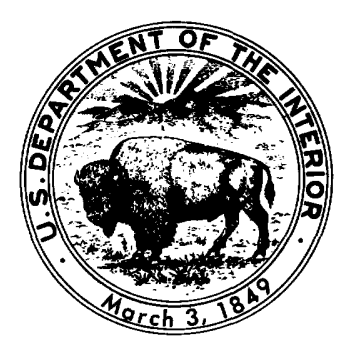

UNITED STATES GOVERNMENT PRINTING OFFICE, WASHINGTON: 1976 


\section{UNITED STATES DEPARTMENT OF THE INTERIOR \\ THOMAS S. KLEPPE, Secretary}

\section{GEOLOGICAL SURVEY}

V. E. McKelvey, Director

Library of Congress Cataloging in Publication Data

Poore, Richard Z.

Microfossil correlation of California, Lower Tertiary sections. (Shorter contributions to general geology)

(Geological Survey Professional Paper 743-F)

Bibliography: p. 8.

Supt. of Docs. no.: I 19.16:743-F

1. Paleontology-Tertiary. 2. Foraminifera, Fossil. 3. Paleontology-Tertiary. 4. Stratigraphic correlation-California.

5. Micropaleontology-California. I. Title. II. Series. III. Series: United States Geological Survey Professional Paper 743-F;

QE767.P66

$76-608044$

For sale by the Superintendent of Documents, U.S. Government Printing Office Washington, D.C. 20402

Stock Number 024-001-02855-7 


\section{CONTENTS}

Abstract.
Introduction
Acknowledgments
Vorrelations of the sections
Vaca Valley
Tres Pinos syncline
Upper Reliz Creek
New Idria $\quad$ Lodo Gulch, Oil City, and Garza Creek
Media Agua Creek
$\quad$ Upper Cañada de Santa Anita
Las Cruces
Simi Valley
Comparison of correlations
Age assignments
References cited

\section{ILLUSTRATIONS}

[Plates in pocket]

Plate 1. Correlation chart showing relation between calcareous nannoplankton zones and provincial benthonic foraminiferal stages.

2. Correlation chart showing relation between calcareous nannoplankton zones and planktonic foraminiferal zones.

2. Calcareous nannoplankton zonation of Bukry (1973)

3. P-zone system used for Paleogene planktonic foraminiferal zones

4. Comparison of first occurrences of Discoaster sublodoensis, Lophodolithus mochlophorus, and Rhabdosphaera tenuis -- 3

5. Summary of relations between calcareous nannoplankton zones and provincial benthonic fora miniferal stages shown

on plate 1 . 



\title{
MICROFOSSIL CORRELATION OF CALIFORNIA LOWER TERTIARY SECTIONS: A COMPARISON
}

\author{
By Richard Z. Poore
}

\begin{abstract}
Data on benthonic foraminifers and calcareous planktonic microfossils that are summarized for several California lower Tertiary sections suggest that the California provincial benthonic foraminiferal stages, as developed in these sections, are at least partly coeval. Age assignments based on calcareous nannoplankton indicate that, in general, Ynezian faunas represent the Paleocene, whereas Bulitian, Penutian, and some Ulatisian faunas represent the early Eocene. The remaining Ulatisian and basal Narizian faunas considered are referable to the middle Eocene.
\end{abstract}

\section{INTRODUCTION}

Correlation and age assignments of Pacific coast lower Tertiary sections are normally based on the provincial benthonic foraminiferal stages of Mallory (1959). Recent studies (Steineck and Gibson, 1971; Schmidt, 1970, 1975; Bukry and others, 1976) have suggested discrepancies between correlations and age determinations based on benthonic foraminifers and those based on calcareous planktonic microfossils (planktonic foraminifers and calcareous nannoplankton).

This study was initiated to synthesize some of the existing microfossil data for several west coast sections in order to delineate problem areas and to aid in the planning of future research projects.

General locations of the sections considered are shown in figure 1. Detailed information on the localities and samples can be found in Bramlette and Sullivan (1961), Sullivan (1964, 1965), and Mallory $(1959,1970)$ and papers cited in those reports. Calcareous nannoplankton identifications are from Bramlette and Sullivan (1961) and Sullivan (1964, 1965). Planktonic foraminifers were identified by Poore for selected samples from Lodo Gulch; otherwise, the identifications of Schmidt $(1970,1975)$ are used.

\section{ACKNOWLEDGMENTS}

For helpful comments and suggestions, I thank David Bukry, Weldon Rau, Washington Dept. Natural Resources, and William Sliter.

\section{CORRELATIONS OF THE SECTIONS}

With few exceptions, the stratigraphic nomenclature, provincial benthonic foraminiferal stage determinations, and correlation of the sections follows Sullivan (1965). Departures from Sullivan's correlations (1965, fig. 2) are discussed below. Age assignments of the provincial stages are from Mallory $(1959,1970)$. Calcareous nannoplankton data were taken from the occurrence charts of Bramlette and Sullivan (1961)

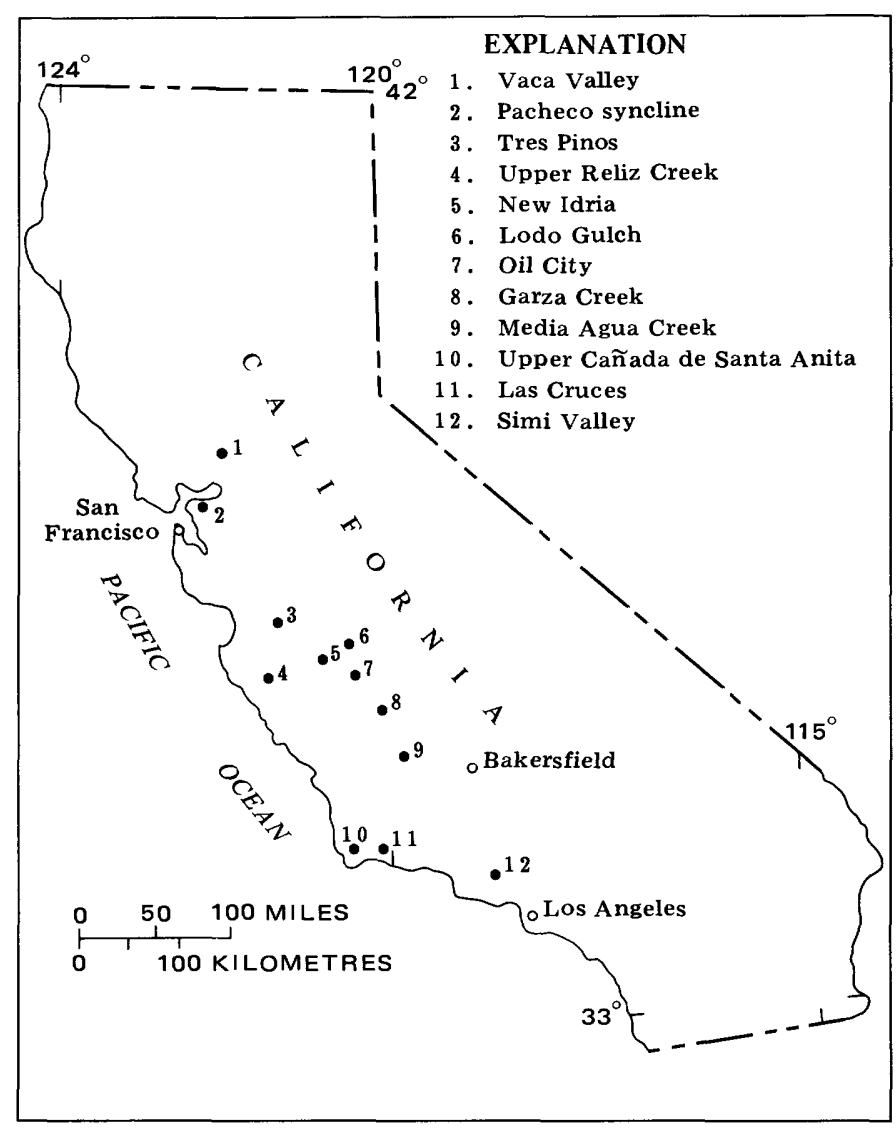

Figure 1.-Location of the California lower Tertiary sections considered in this study. 


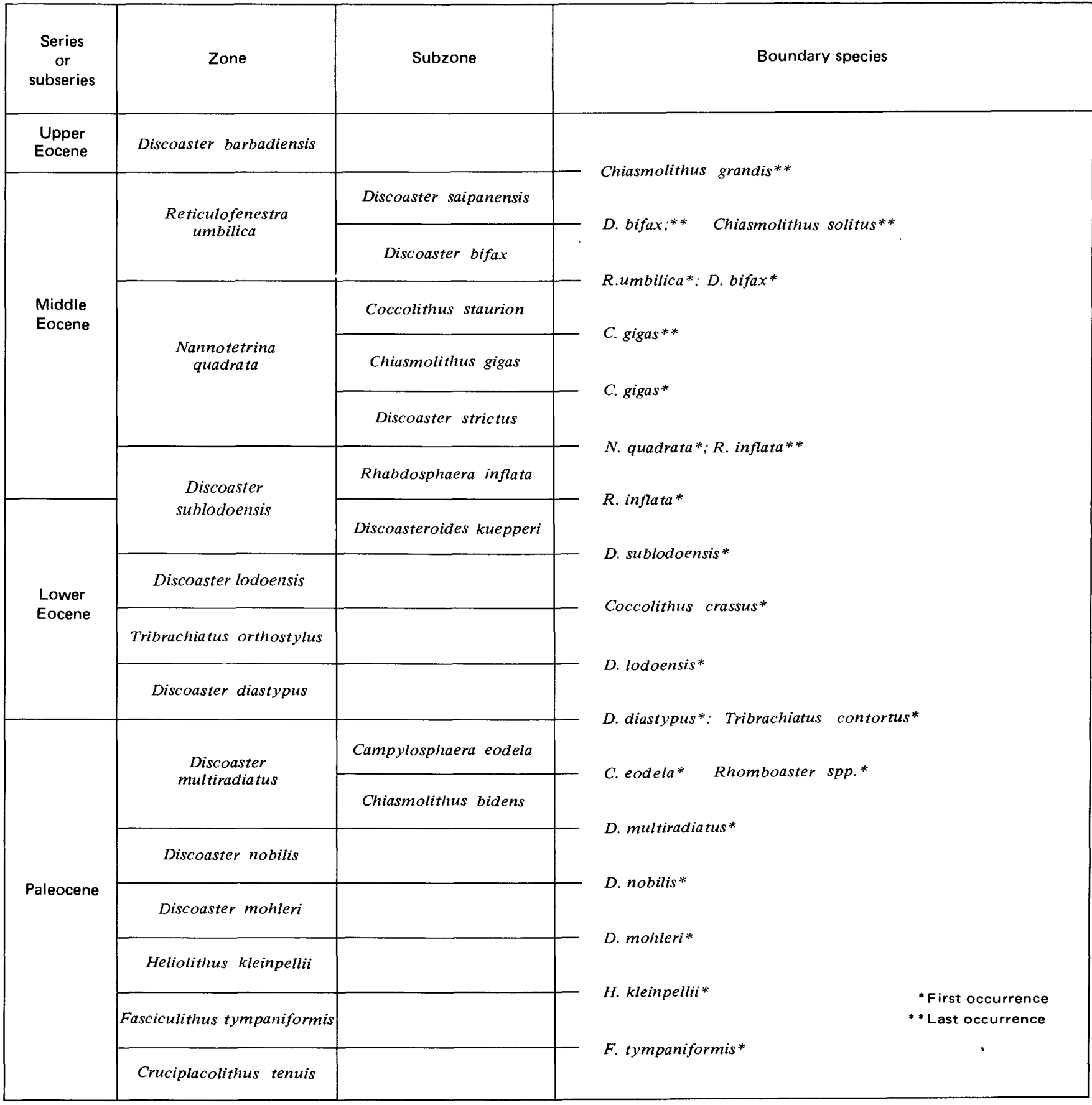

FIGURE 2.-Calcareous nannoplankton zonation. For discussion of zonation see Bukry (1973). Correlation of zonation to international standard follows Bukry (1973).

and Sullivan $(1964,1965)$. These data can be "codified" into any number of informal or formal zonations (see Hay and Steinmetz, 1973). The zonation proposed by Bukry (1973), which relies heavily on first occurrences, is used in this report (fig. 2). Age assignments of the zones follow Bukry (1973).

Planktonic foraminifers from these sections have not received as much study as the other two groups of mi- crofossils. However, data for four of the sections are available. For convenience, the P-zone system of Berggren (1972) and the classification of Schmidt (1970) are used for these data (fig. 3).

Plates 1 and 2 summarize correlations of the sections determined by the three groups of microfossils. Zone and provincial stage boundaries are, in general, drawn between available control points. 


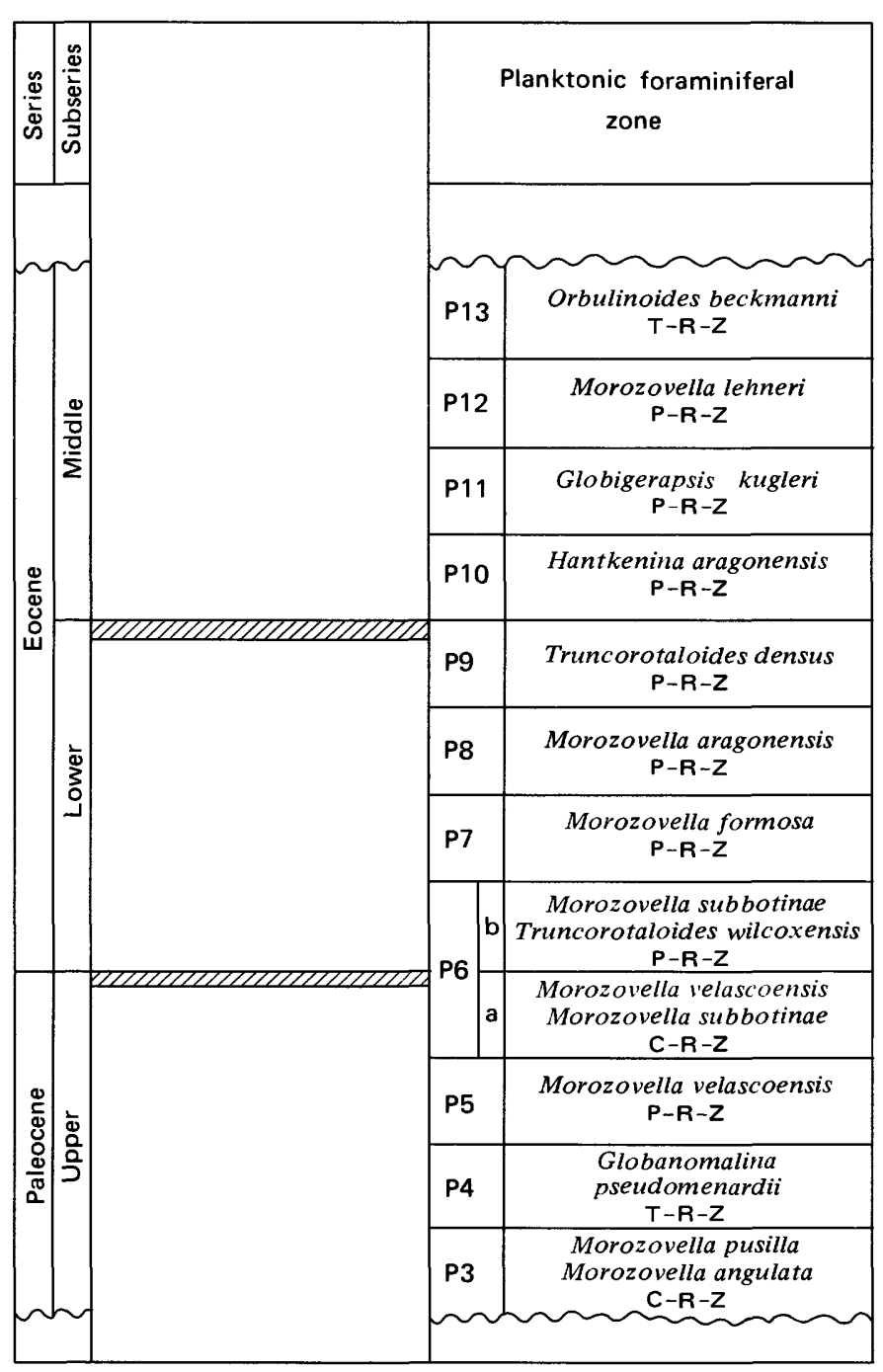

Figure 3.-P-zone system used for lower Tertiary planktonic foraminiferal zones. Modified from Berggren (1972, fig. 5). Classification follows Schmidt (1970). Slashed lines, approximate boundaries between subseries. Lower Eocene-middle Eocene boundary (that is, Ypresian-Lutetian boundary) probably occurs within the P-9-zone (see Luterbacher, 1964; Berggren, 1971a, fig. 3). T-R-Z, total range zone; $\mathrm{P}-\mathrm{R}-\mathrm{Z}$, partial range zone; and $\mathrm{C}-\mathrm{R}-\mathrm{Z}$, concurrent range zone. For discussion of zonation see Berggren (1971b) and Blow (1969).

\section{VACA VALLEY}

Following Sullivan (1965, p. 18), the UlatisianNarizian boundary in the Vaca Valley section is placed between samples A-4782S and A-4783A. This boundary coincides with the Discoaster sublodoensisNannotetrina quadrata Zone boundary, as $N$. quadrata (Bramlette and Sullivan) Bukry first occurs in A-4783A. Although the lowest occurrence of Discoaster sublodoensis Bramlette and Sullivan is in A-4781H, the seven samples below this occurrence are assigned to the $D$. sublodoensis Zone because of the occurrences of Lophodolithus mochlophorus Deflandre and Rhabdosphaera tenuis Bramlette and Sullivan in A-4781A.

In the four sections that contain the best nannoplankton assemblages on either side of the UlatisianNarizian boundary (Lodo Gulch, Media Agua Creek, Las Cruces, and Upper Cañada de Santa Anita), the lowest occurrences of Lophodolithus mochlophorus and Rhabdosphaera tenuis correspond closely with the lowest occurrence of Discoaster sublodoensis (see fig. 4). These observations suggest that the first occurrences of $L$. mochlophorus and $R$. tenuis can be used to approximate the first occurrence of $D$. sublodoensis in the sections where $D$. sublodoensis is absent or very rare.

\section{PACHECO SYNCLINE}

Provincial stage assignments for the Pacheco syncline section follow Sullivan $(1965$, p. 19; fig. 2) with the exception that the Ulatisian-Narizian boundary is placed approximately halfway between available control points (that is, samples A-6686 and A-6663). This boundary corresponds with the placement of the lower boundary of the Nannotetrina quadrata Zone based on the occurrence of $N$. quadrata in A-6663. The presence of Chiasmolithus gigas (Bramlette and Sullivan) Radomski in A-6689 indicates that this section extends at least into the middle Chiasmolithus gigas Subzone of the Nannotetrina quadrata Zone.

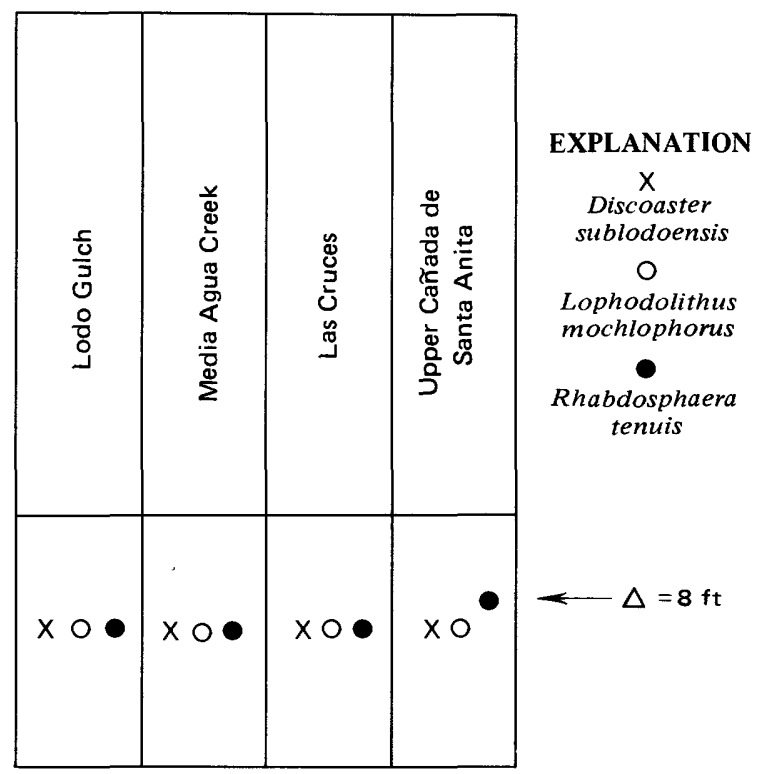

FIGURE 4.-Comparison of first occurrences of Discoaster sublodoensis, Lophodolithus mochlophorus, and Rhabdosphaera tenuis in four sections. $\Delta=$ stratigraphic difference in feet between samples. Data from Bramlette and Sullivan (1961) and Sullivan (1965). Plot suggests that the first occurrences of Lophodolithus mochlophorus and Rhabdosphaera tenuis can be used to approximate the first occurrence of Discoaster sublodoensis in sections where $D$. sublodoensis is absent or poorly represented. 
In the absence of Discoaster sublodoensis, the lowest occurrences of Lophodolithus mochlophorus and Rhabdosphaera tenuis in A-6666 delineate the base of the Discoaster sublodoensis Zone.

The presence of Heliolithus riedelii Bramlette and Sullivan in A-6658 and of Fasciculithus involutus Bramlette and Sullivan in A-6658 and A-6661 coupled with the absence of Discoaster multiradiatus Bramlette and Riedel suggests that these samples should be assigned to the Discoaster nobilis Zone.

A sample from the base of Weaver's (1953) Las Juntas Shale (Smith, 1957, sample 6662) is considered by Mallory (1959) to be Bulitian. As Sullivan $(1964,1965)$ does not list this sample in his occurrence charts, I assume that it is barren of calcareous nannoplankton. Because of the uncertainty involved, the $D$. sublodoensis Zone is extended only to below A-6666.

\section{TRES PINOS}

Provincial stage assignments for the Tres Pinos section follow Sullivan (1965). However, the position of the Penutian-Ulatisian boundary in this section is not clear. Sullivan $(1965$, p. 21) placed this boundary within the lower Los Muertos Creek Formation (above B-7242), but he noted that the sparse fauna from B-7242 "*** could just as well be of Ulatisian age." Sullivan's (1965, text fig. 2) placement of this boundary is adopted here, and the top of the Ulatisian is drawn approximately halfway between B-7235 (which contains a Narizian fauna, Sullivan, 1965, p. 21, and Karr, 1962, checklist) and B-7242. This boundary corresponds to the base of the Nannotetrina quadrata Zone, as $N$. quadrata is present in B-7235.

The occurrence of Coccolithus crassus Bramlette and Sullivan in B-7205 marks the base of the Discoaster lodoensis Zone. Discoaster sublodoensis, Lophodolithus mochlophorus, and Rhabdosphaera tenuis are not recorded at this section. For this reason, samples B-7205 to $\mathrm{B}-7242$ are assigned to the $D$. lodoensis Zone, and the $D$. sublodoensis Zone is tentatively dashed in above B-7242.

The flora reported for sample B-7204 is relatively sparse, but the presence of Discoaster diastypus Bramlette and Sullivan indicates that the sample is within either the Discoaster diastypus Zone or the Tribrachiatus orthostylus Zone. Samples B-7202 to B-7250 contain a flora representative of the Discoaster multiradiatus Zone. Sample B-7239, which contains Fasciculithus involutus, Heliolithus kleinpellii Sullivan and $H$. riedelii but lacks Discoaster nobilis Martini (=Discoaster falcatus Bramlette and Sullivan, Hay and others, 1967 , p. 435), is assigned to the Discoaster mohleri Zone.

\section{UPPER RELIZ CREEK}

Provincial stage assignments for the Upper Reliz Creek section follow Sullivan (1965) (see also Mallory, 1959 , p. 36). The calcareous nannoplankton assemblages in the samples from this section are indicative of the Discoaster lodoensis Zone.

\section{NEW IDRIA}

Provincial stage assignments for the New Idria section follow Sullivan (1965, p. 22) with the exception that the Ynezian-Bulitian boundary is placed halfway between samples B-4861A and B-4861.

Samples B-4861 to B-4898 contain assemblages representative of the Discoaster lodoensis Zone. Sample B-4861A, which contains Heliolithus riedelii, is assigned to the Discoaster mohleri Zone, but it could represent the Discoaster nobilis Zone.

\section{LODO GULCH, OIL CITY, AND GARZA GREEK}

Provincial stage assignments for the Lodo Gulch, Oil City, and Garza Creek sections follow Sullivan (1965, text fig. 2) except that the Ulatisian-Narizian boundary, which Sullivan places directly at the top of the Ulatisian (Mallory, 1959, p. 51) Canoas Silt at Oil City, is drawn somewhat higher.

Although not reported by Bramlette and Sullivan (1961), Discoaster mohleri Bukry and Percival (=Discoaster gemmeus Stradner, in part, see Bukry and Percival, 1971) is present in sample $6+1$ (Hay and others, 1967 , p. 436). Therefore, sample $6+1$, containing Discoaster mohleri and Heliolithus riedelii, is assigned to the Discoaster mohleri Zone, and sample 7, with Discoaster nobilis, is assigned to the Discoaster nobilis Zone. The remaining samples are assigned to the Discoaster multiradiatus Zone to Nannotetrina quadrata Zone on the basis of the lowest occurrences of Discoaster multiradiatus, D. diastypus, D. lodoensis Bramlette and Riedel, Coccolithus crassus, Discoaster sublodoensis, and Nannotetrina quadrata in samples 19, 23, 25, 50 , OC- 1 , and GC-1, respectively.

Data on planktonic foraminifers from the Lodo Gulch section given by Schmidt (1970, text fig. 10) have been supplemented by examination of samples 20 to 40 of Israelsky (1951). Schmidt $(1970,1975)$ noted that a paraconformity may exist in the lower part of this section ( $\sim 150 \mathrm{~m}$ [492 ft] above the base), citing the absence of nannoplankton and planktonic foraminiferal zones as supporting evidence. The nannoplankton zonation used here (see discussion above and pl. 2), however; does not reveal a significant missing interval. Alternatively, if the zonation of Martini $(1970,1971)$ is used, one zone (Marthasterites contortus Zone) may be absent (Hay and others, 1967). 
Although the faunas from the interval between the highest occurrence of Morozovella velascoensis velascoensis (Cushman) (sample 32) and the lowest occurrence of typical Morozovella aragonensis aragonensis (Nuttall) (sample 36) are relatively sparse, sample 23 contains a fauna with good representatives of Morozovella subbotinae (Morozova) and M. marginodentata (Subbotina). Samples below this (that is, $20,21,30$, and 32) contain forms transitional between Morozovella aequa (Cushman and Renz) and M. subbotinae. Thus the $\mathrm{P} 5 / \mathrm{P} 6$ boundary is placed between samples 32 and 23 , and the $\mathrm{P} 6 / \mathrm{P} 7$ boundary between samples 35 and 36 . The section does appear to be highly condensed in this interval; if a paraconformity does exist, it probably represents the lower part of $\mathrm{P} 6$.

The occurrence of Morozovella aragonensis caucasica (Glaessner) and "Subbotina" senni (Beckmann) in Schmidt's sample $0256(270 \mathrm{~m}[\sim 885 \mathrm{ft}]$ below the Domengine Formation) suggests that the $\mathrm{P} 7 / \mathrm{P} 8$ boundary is near this sample. The lowest part of the section is assigned to $\mathrm{P} 4$ on the basis of the occurrence of Globanomalina pseudomenardii (Bolli) in sample $0222(=6+1)$.

\section{MEDIA AGUA CREEK}

Provincial stage assignments for the Media Agua Creek section follow Sullivan (1965) and Mallory (1959, 1970). Sample A-7079, containing Discoaster nobilis (as Discoaster falcatus) and Heliolithus riedelii, is referable to the Discoaster nobilis Zone. The flora from A-7083, which consists solely of Fasciculithus involutus, is arbitrarily assigned to the $D$. nobilis Zone, however, it might be as low as the Heliolithus kleinpellii Zone. The assemblage reported for A-7078 is referable to the Discoaster diastypus Zone. Thus, the Discoaster multiradiatus Zone is absent at this section. The Tribrachiatus orthostylus Zone to Nannotetrina quadrata Zone are recognized by the lowest occurrences of Discoaster lodoensis, Coccolithus crassus, Discoaster sublodoensis, and Nannotetrina quadrata in A-7075, A-7091, A-7052, and A-7009, respectively.

Samples A-7083, A-7081, and A-7079, with Globanomalina pseudomenardii (Schmidt, 1970, p. 62) represents P 4 (pl. 2). Samples A-7078, A-7077, and A-7076, with Morozovella subbotinae and Pseudohastigerina wilcoxensis (Cushman and Ponton), are referable to $\mathrm{P} 6$ (upper part, or $\mathrm{P} 6 \mathrm{~b}$ ). Thus the hiatus in this section suggested by the calcareous nannoplankton data is also evident in the planktonic foraminiferal assemblages.

The appearance of Morozovella aragonensis aragonensis in A-7075 marks the base of $\mathrm{P} 7$, and the occurrence of "Subbotina" senni in A-7061 probably approximates the lower limit of P 8. Zones P 9 and P 10 are indicated by the first occurrences of Truncorotaloides densus (Cushman) in A-7050 and Clavigerinella eocanica (Nuttall) and "Globorotalia" wilsoni (Cole) in A-7039. The remaining samples above A-7039 are probably within P 10.

\section{UPPER GAÑADA DE SANTA ANITA}

Provincial stage assignments for the upper Cañada de Santa Anita section follow Sullivan (1965), with samples A-8926 to A-8939A representing the Ynezian, A-8940 the Bulitian, A-8941 and A-8940 Penutian, and A-8947 to A-8954 the Ulatisian.

Samples A-8926 to A-8936 are referred to the Discoaster nobilis Zone on the basis of the occurrence of Heliolithus riedelii in this interval along with the sporadic occurrence of Discoaster nobilis in A-8930 and A-8936. The lowest three samples could represent the Discoaster mohleri Zone. The abundant occurrence of Discoaster multiradiatus in A-8939A without Discoaster diastypus places this sample in the $D$. multiradiatus Zone.

The lowest occurrence of Coccolithus crassus (=base Discoaster lodoensis.Zone) in A-8941 is coincident with the lowest occurrences of Discoaster lodoensis and $D$. diastypus as well as several other lower Eocene taxa. The Discoaster diastypus and Tribrachiatus orthostylus Zones are therefore not represented.

Rhabdosphaera inflata Bramlette and Sullivan occurs in A-8948, one sample lower than the lowest occurrences of Discoaster sublodoensis and Lophodolithus mochlophorus in A-8949. This out-of-sequence occurrence is difficult to evaluate, as $R$. inflata occurs in only one other section (Bramlette and Sullivan, 1961). As a minimum estimate, therefore, the base of the $D$. sublodoensis Zone is placed below A-8948.

\section{LAS CRUCES}

Provincial stage assignments for the Las Cruces section follow Sullivan (1965) and Kleinpell and Weaver (1963, fig. 8). Sample A-8855, containing Coccolithus crassus and Discoaster lodoensis, is referable to the Discoaster lodoensis Zone. The Discoaster sublodoensis and Nannotetrina quadrata Zones are recognized by the lowest occurrences of their respective zonal markers in D-1017 and A-8862.

Data concerning planktonic foraminifers from the Las Cruces section are very sparse. Schmidt (1970) reports a fauna that includes Truncorotaloides aspensis (Colom), T. rotundimarginatus (Subbotina), Hantkenina dumblei Weinzierl and Applin, and Globigerapsis index (Finlay) from a level equivalent to A-8862. I tentatively refer this assemblage to $P 11$. The upper Anita Shale contains a fauna representative of the 
"Subbotina" senni Zone of Schmidt (1970), and this fauna is here referred to $\mathrm{P} 8$ because of the presence of Morozovella aragonensis caucasica and the absence of Truncorotaloides densus.

\section{SIMI VALLEY}

Provincial Stage assignments for the Simi Valley section follow Sullivan (1965).

Samples A-7616 and A-7617 are referred to the Heliolithus kleinpellii Zone because of the presence of $H$. kleinpellii. The lowest sample from the section (A7612) yielded rare specimens of Fasciculithus involutus, so sample A-7612 is also assigned to the $H$. kleinpellii Zone. Samples A-7621 and A-7622 are assigned to the Discoaster mohleri Zone because of the presence of Heliolithus riedelii below the lowest occurrence of Discoaster nobilis in A-7623.

The first definite occurrence of Discoaster multiradiatus in A-7633 is preceded by two questionable occurrences in A-7628 and A-7630. The base of the Discoaster multiradiatus Zone (figs. 4 and 5 ) has been placed approximately halfway between A-7628 and A-7633 and is queried to indicate that it may be drawn slightly low. The sparse nannoplankton reported from samples A-7642 to A-7652 are assigned to the Discoaster lodoensis Zone because of the lowest occurrence of Coccolithus crassus in A-7642. Thus this interval of the Santa Susana Formation resembles the Anita Shale discussed earlier in that the Discoaster diastypus and Tribrachiatus orthostylus Zones are not represented.

The lower half of the section $(295-607 \mathrm{~m}[\sim 970$ $1990 \mathrm{ft}$ ] below base of the Llajas Formation) contains Globanomalina pseudomenardii and is assigned to $\mathrm{P} 4$. The overlying $64 \mathrm{~m}(210 \mathrm{ft})$ is tentatively assigned to $\mathrm{P}$ 5 because of the presence of Morozovella velascoensis (s.l.) and the absence of $M$. subbotinae (see Schmidt, 1970). Planktonic foraminiferal assemblages reported from samples higher in the section cannot be readily assigned to a zone.

In the Simi Valley section, there is a significant discrepancy between ages indicated by the calcareous nannoplankton and planktonic foraminifers within the upper Santa Susana Formation (see pl. 2). The Eocene assignment indicated by the presence of Coccolithus crassus in many of these samples is supported by the occurrence of Discoaster diastypus in A-7644 and A-7648 and of Chiasmolithus grandis (Bramlette and Riedel) Radomski in A-7648 and A-7649. To my knowledge, these taxa are not known from Paleocene strata.

At the present time, data are insufficient to resolve this problem, and further work in this area is war- ranted. The calcareous nannoplankton determination, which is based on first occurrences, is favored over the determination suggested by the planktonic foraminiferal data of Schmidt (1970).

In the remainder of this section and in the other three sections where data on both calcareous nannoplankton and planktonic foraminifers are available, correlations and age determinations based on the calcareous plankton are in basic agreement.

\section{COMPARISON OF CORRELATIONS}

Examination of figure 4 indicates that correlations of the sections by calcareous nannoplankton and benthonic foraminifers agree in some instances and disagree in others. For example, the Ulatisian-Narizian boundary basically coincides with the boundary between the Discoaster sublodoensis and Nannotetrina quadrata Zones. And Ulatisian faunas, as reported in these sections, are closely associated with the Discoaster sublodoensis Zone and the upper part of the Discoaster lodoensis Zone. In contrast, strata assigned to the Bulitian provincial benthonic foraminiferal stage contain floras referable to the Paleocene Discoaster multiradiatus Zone through the Eocene Discoaster lodoensis Zone. The associations of provincial benthonic foraminiferal stages and calcareous nannoplankton zones exhibited on plate 1 are summarized in figure 5 . The Media Agua Creek section, which contains the type zones of the Ynezian and Bulitian stages, has been extensively studied for benthonic foraminifers by Mallory, $(1959,1970)$ and is tabulated separately. The relations seen in this figure are similar to those reported by Bukry, Brabb, and Vedder (1976) from a compilation of unpublished data and an examination of a different suite of samples in the Coast and Peninsular Ranges of California. The composite diagram (fig. 5) suggests that the provincial benthonic foraminiferal stages as developed in these sections are in part coeval.

\section{AGE ASSIGNMENTS}

Nannoplankton from the lower type Anita Shale (= type Ynezian, Mallory, 1959) are referable to the Discoaster nobilis Zone except for one sample, A-8939A which represents the Discoaster multiradiatus Zone. At Media Agua Creek, the type Silicosigmolina californica Zone is associated with the $D$. nobilis Zone, whereas the type Bulimina excavata Zone corresponds to the Eocene Discoaster diastypus Zone. Except for this one Eocene occurrence, Ynezian faunas are associated with Paleocene calcareous nannoplankton zones (see pl. 1 and fig. 5).

Calcareous nannoplankton are not recorded from the type Bulitian. At Media Agua Creek, the type zones of 


\begin{tabular}{|c|c|c|c|c|c|c|c|c|c|c|}
\hline \multicolumn{5}{|c|}{$\begin{array}{l}\text { Provincial benthonic foraminiferal } \\
\text { stages, composite minus Media } \\
\text { Agua Creek }\end{array}$} & \multirow{2}{*}{ Calcareous nannoplankton zone } & \multicolumn{5}{|c|}{$\begin{array}{l}\text { Provincial benthonic foraminiferal } \\
\text { stages, Media Agua Creek }\end{array}$} \\
\hline 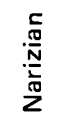 & 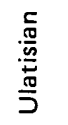 & 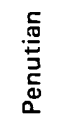 & 营 & 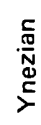 & & 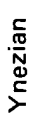 & & 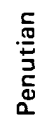 & 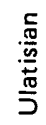 & 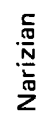 \\
\hline & Not & \multicolumn{2}{|c|}{ studied } & & Reticulofenestra umbilica & & Not & \multicolumn{2}{|c|}{ studied } & \\
\hline 园 & & & & & Nannotetrina quadrata & & & & & \\
\hline 泣 & & & & & Discoaster sublodoensis & & & & & \\
\hline & 娄 & & 网 & & Discoaster lodoensis & & & & & \\
\hline & & 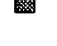 & & & Tribrachiatus orthostylus & & & & & \\
\hline & & & & & Discoaster diastypus & & & & & \\
\hline & & & - & 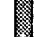 & Discoaster multiradiatus & & & & & \\
\hline & & & & 1 & Discoaster nobilis & -1) & & & & \\
\hline & & & & 畨 & Discoaster mohleri & & & & & \\
\hline & & & & $?$ & Heliolithus kleinpellii & & & & & \\
\hline & & & & & Fasciculithus tympaniformis & & & & & \\
\hline & & & & & Cruciplacolithus tenuis & & & & & \\
\hline
\end{tabular}

FIGURE 5.-Summary of associations of provincial benthonic foraminiferal stages (vertical bars) with calcareous nannoplankton zones exhibited on plate 1 .

the Bulitian are associated with the Eocene Tribrachiatus orthostylus Zone, and with the exception of the Simi Valley section, Bulitian faunas in the remaining sections are associated with Eocene calcareous nannoplankton zones. Thus, in general, in these sections Ynezian faunas are indicative of a Paleocene age, and Bulitian faunas are referable to the early Eocene.

The two benthonic foraminiferal zones of the type Penutian at Media Agua Creek are associated with the upper Tribrachiatus orthostylus Zone and the Discoaster lodoensis Zone.

The type Ulatisian in the Vaca Valley and the two zones of the Ulatisian as developed at Media Agua Creek correspond to the Discoaster sublodoensis Zone. The basal Narizian fauna at Media Agua Creek as well as Narizian faunas in the remaining sections are associated with the Nannotetrina quadrata Zone.

Discoaster sublodoensis occurs in the lower Lutetian of the Paris Basin (Bouché, 1962) in association with a flora representative of the upper Discoaster sublodoensis Zone (Hay and others, 1967). Furthermore, the Discoaster sublodoensis Zone and at least the lower part of the Nannotetrina quadrata Zone (of Bukry, 1973) are associated with the middle Eocene Hantkenina aragonensis Zone (Hay and others, 1967). Whether one considers the base of the Lutetian to be within the Discoaster sublodoensis Zone or prefers to place it somewhat lower-at the base of the Discoaster sublodoensis Zone (Martini, 1970; Hay and others, 1967; Schmidt, 1975) or in the upper Discoaster lodoensis Zone (Gartner, 1971) -is of minor consequence. Rather, the important point is that in terms of correlation to the international standard, Ulatisian faunas usually indicate a middle Eocene age and lower Narizian faunas at least are also of middle, instead of late, Eocene age. 


\section{REFERENCES CITED}

Berggren, W. A., 1971a, Multiple phylogenetic zonations of the Cenozoic based on Planktonic Foraminifera: Internat. Conf. Planktonic Microfossils, 2d, Roma 1970, Proc., p. 41-56.

1971b, Tertiary boundaries and correlations, in Funnel, B. F., and Riedel, W. R., eds. Micropaleontology of the oceans: Cambridge, Cambridge Univ. Press, p. 693-809.

1972, A Cenozoic time-scale-some implications for regional geology and paleobiogeography: Lethaia, v. 5, p. 195-215.

Blow, W. H., 1969, Late middle Eocene to Recent planktonic foraminiferal biostratigraphy: Internat. Conf. Planktonic Microfossils, 1st, Geneva 1967, Proc., p. 199-422.

Bouché, P. M., 1962, Nannofossiles calcaires du Lutetien du Bassin de Paris: Rev. Micropaleontologie, v. 5, p. 75-103.

Bramlette, M. N., and Sullivan, F. R., 1961, Coccolithophorids and related nannoplankton of the early Tertiary in California: Micropaleontology, v. 7, p. 129-174.

Bukry, David, 1973, Low-latitude coccolith biostratigraphic zonation: Deep Sea Drilling Proj. Initial Repts., v. 15, p. 685-703.

Bukry, David, Brabb, E. E., and Vedder, J. G., 1976, Correlation of Tertiary nannoplankton assemblages from the Coast and Peninsular Ranges of California: Latin American Geol. Cong., 2d, Caracas 1973 (in press).

Bukry, David, and Percival, S. F., Jr., 1971, New Tertiary calcareous nannofossils: Tulane Studies Geology and Paleontology, v. 8, p. 123-146.

Gartner, S., Jr., 1971, Nannofossil zonation of the Paleocene-Eocene sediments penetrated in JOIDES Blake Plateau Cores J-3, J-4 and J-6B: Ann. Inst. Geol. Publ. Hungary, v. 54, p. 69-77.

Hay, W. W., Mohler, H. P., Roth, P. H., Schmidt, R. R., and Boudreaux, J. E., 1967, Calcareous nannoplankton zonation of the Cenozoic of the Gulf Coast and Caribbean-Antillean area and transoceanic correlation: Gulf Coast Assoc. Geol. Socs. Trans., v. 17 , p. $428-480$.

Hay, W. W., and Steinmetz, J. C., 1973, Probabilistic analysis of distribution of late Paleocene-early Eocene calcareous nannofossils: Proceedings of Symposium on Calcareous Nannofossils, Soc. Econ. Paleontologists and Mineralogists, Gulf Coast Sec., 1973 Ann. Mtg., p. 58-70.

Israelsky, M. C., 1951, Foraminifera of the Lodo Formation central California. General Introduction and Pt. 1, Arenaceous Foraminifera: U.S. Geol. Survey Prof. Paper 240-A, p. A1-A29.
Kaar, R. F., 1962, Lower Tertiary Foraminifera from north central San Benito County, California: California Univ. (Berkeley), M.A. thesis, $144 \mathrm{p}$.

Kleinpell, R. M., and Weaver, D. W., 1963, Oligocene biostratigraphy of the Santa Barbara embayment, California: California Univ. Pubs. Geol. Sci., v. 43, 250 p.

Luterbacher, H., 1964, Studies in some Globorotalia from the Paleocene and lower Eocene of the Central Apennines: Eclogae Geol. Helvetiae, v. 57, p. 631-730.

Mallory, V. S., 1959, Lower Tertiary biostratigraphy of the California Coast Ranges: Tulsa, Okla., Am. Assoc. Petroleum Geologists, $416 \mathrm{p}$.

1970, Lower Tertiary Foraminifera from the Media Agua Creek Drainage Area Kern County, California: Thomas Burke Memorial Washington State Museum Research Rep. 2, 211 p.

Martini, E., 1970, Standard Paleogene calcareous nannoplankton zonation: Nature, v. 226 , p. $560-561$.

1971, Standard Tertiary and Quaternary calcareous nannoplankton zonation: Internat. Conf. Planktonic Microfossils, 2d, Roma 1970, Proc., p. 739-785.

Schmidt, R. R., 1970, Planktonic Foraminifera from the lower Tertiary of California: California Univ. (Los Angeles), Ph.D. thesis, $339 \mathrm{p}$.

1975, Upper Paleocene-Middle Eocene planktonic biostratigraphy from the Great Valley of California and adjacent areas, and correlation to the West Coast Microfaunal Stages, in Paleogene Symposium and Selected Technical Papers: Am. Assoc. Petroleum Geologists, Soc. Econ. Paleontologists and Mineralogists, and Soc. Explor. Geophysicists, Pacific Sec. Ann. Mtg., 1975, p. 439-455.

Smith, B. Y., 1957, Lower Tertiary Foraminifera from Contra Costa County, California: California Univ. Pubs. Geol. Sci., v. 32, p. 127-242.

Steineck, P. L., and Gibson, J. M., 1971, Age and correlation of the Eocene Ulatisian and Narizian Stages, California: Geol. Soc. American Bull., v. 82, p. 477-480.

Sullivan, F. R., 1964, Lower Tertiary nannoplankton from the California Coast Ranges-Pt. I, Paleocene: California Univ. Pubs. Geol. Sci., v. 44, p. 163-228.

1965, Lower Tertiary nannoplankton from the California, Coast Ranges-Pt. II, Eocene: California Univ. Pubs. Geol. Sci., v. 53 , p. $1-75$.

Weaver, C. E., 1953, Eocene and Paleocene deposits at Martinez, California: Washington [State] Univ. Pubs. in Geology, v. 7, $102 \mathrm{p}$. 